\title{
Diseminasi Teknologi Mesin Pengupas Kulit Ari Kacang Hijau Sistem Roller Terbarukan di Desa Karangpaing Kecamatan Penawangan Kabupaten Grobogan
}

\author{
Achmad Buchori, Yuris Setyoadi, Fafa Nurdyansyah, Sigit Ristanto \\ Universitas PGRI Semarang, Indonesia \\ buccherypgri@gmail.com
}

Received: $18^{\text {th }}$ November 2019 | Accepted: $29^{\text {th }}$ July 2020 | Publihsed: $20^{\text {th }}$ August 2020

Key word:

Dissemination;

roller system;

mung bean

peeler

\section{Kata Kunci}

Diseminasi;

sistem roller; alat mesin pengupas

kulit ari kacang

hijau

\section{Abstract}

Karangpaing Village is a green bean farming center. However, post-harvest processing is still manual so that production is small. This activity of disseminating technology products to the community aims to improve the welfare of citizens by increasing the production capacity of green beans with a renewable roller system, as well as increasing the value of their sales and marketing. This service method includes interviews, observation, socialization, discussion, practice and question and answer. The outputs generated from this activity include Karangpaing green bean farmers who can operate pulping machines, diversify mung bean products, carry out good financial management and marketing. This activity has been handed over to 5 units of mung bean epidermis peeler and has been trained to process green beans into several processed variations such as green bean extract milk, bakpia, bakpao and others, so that the residents are very enthusiastic.

\section{Abstrak}

Desa Karangpaing merupakan sentra pertanian kacang hijau. Namun, pengolahan pasca panen masih manual sehingga produksinya kecil. Kegiatan diseminasi produk teknologi ke masyarakat ini bertujuan untuk meningkatkan kesejahteraan warga melalui peningkatan kapasitas produksi kacang hijau dengan sistem roller terbarukan, serta peningkatan nilai penjualan dan pemasarannya. Metode pengabdian ini antara lain wawancara, observasi, sosialisasi, diskusi, praktek dan Tanya jawab. Luaran yang dihasilkan dari kegiatan ini antara lain petani kacang hijau Karangpaing bisa mengoperasikan mesin pengupas, membuat diversifikasi produk kacang hijau, melakukan manajemen keuangan dan pemasaran yang baik. Kegiatan ini telah diserah terimakan 5 unit mesin pengupas kulit ari kacang hijau dan telah dilatih pengolahan kacanghijau menjadi beberapa variasi olahan seperti susu sari kacang hijau, bakpia, bakpao dan lain-lain, sehingga warga sangat antusias. 


\section{PENDAHULUAN}

Desa Karangpaing terletak di Kecamatan Penawangan, yang merupakan salah satu Kecamatan di Kabupaten Grobogan yang berbatasan langsung dengan Kecamatan Brati sebelah utara dan kecamatan godong di sebelah barat, sebelah selatan dengan kecamatan toroh dan di sebelah Timur dengan Kecamatan Purwodadi.

Berdasarkan Sumber data Statistik Desa Karangpaing, Penawangan, Grobogan tahun 2017 dalam hal perekonomian, diketahui bahwa penduduk yang berprofesi sebagai Petani/buruh tani sebanyak 844 orang, Pedagang sebanyak 228 orang, PNS sebanyak 20 orang dan Peternak sebanyak 250 orang. Sementara itu, golongan ekonomi bawah (40\%), menengah (45\%), dan golongan atas (15\%).

Kondisi perekonomian di desa karangpaing berkembang dengan kurang baik. Salah satunya adalah berkaitan belum dimaksimalkannya sumber daya alam desa karangpaing yang memiliki kacang hijau yang melimpah, sehingga perlu dilalukan pemberdayaan masyarakat berkaitan industri kreatif berbasis teknologi tepat guna dengan alat mesin perontok kulit kacang hijau otomatis sehingga produksi meningkat

Desa Karangpaing Penawangan Grobogan terkenal dengan banyaknya petani kacang hijau dengan prosentase $50 \%$ petani kacang hijau, kemudian alat yang digunakan masih sederhana dalam mengupas kacang hijau, hal ini belum dimaksimalkan warga desa karangpaing karena keterbatasan pelatihan tentang menggunakan dan merakit alat pengupas kacang hijau secara otomatis, kemudian dekat dengan kota purwodadi sebagai kota pusat bahan-bahan pembuatan mesin pengupas kacang hijau dan lebih menjanjikan secara ekonomi.

Sumber daya alam yang melimpah di desa Karangpaing belum dimaksimalkan warga karena minimnya pengetahuan berkaitan cara pengupasan kulit ari kacang hijau dan pembuatan alat mesin pengupas kulit ari kacang hijau, berdasarkan survey di lapangan diketahui bahwa warga belum maksimal dalam membuat mesin pengupas kulit ari kacang hijau, sehingga perlu dikenalkan produk mesin pengupas kulit kacang hijau yang telah dibuat di Universitas PGRI Semarang sehingga mampu dimanfaatkan secara maksimal untuk membantu masyarakat. Kegiatan diseminasi ini mengadopsi pengembangan kewirausahaan di Universitas PGRI Semarang yaitu dengan pelatihan yang mendorong dan meningkatkan pengetahuan tentang kewirausahaan, meningkatkan motivasi berwirausaha, serta meningkatkan 
kemampuan dalam manajemen

kewirausahaan (Zuhri dkk., 2019).

Sasaran utama pada program diseminasi produk teknologi ke masyarakat adalah untuk meningkatkan ekonomi masyarakat secara mandiri dan dapat menumbuhkan minat masyarakat yang belum bergabung dengan Kelompok Mukti Tani dan Kelompok Rukun Santoso ini, sehingga kelompok usaha ini bisa berkembang pesat. Program pelatihan dan peningkatan pengetahuan tentang pemanfaatan teknologi tepat guna yaitu penggunaan mesin pengupas kulit ari kacang hijau.

\section{METODE}

Metode dan tahapan dalam penerapan teknologi kepada masyarakat ini ditunjukkan pada Tabel 1. Wawancara dan observasi langsung diterapkan pada untuk Identifikasi kebutuhan masyarakat. Diskusi diterapkan pada kegiatan perancangan alat, pendampingan operasional, pembuatan dan diseminasi teknologi. Selain itu, juga diterapkan metode praktek dan tanya jawab.

Tabel 1. Metode dan Tahapan Diseminasi

\begin{tabular}{lll}
\hline No & \multicolumn{1}{c}{ Kegiatan } & \multicolumn{1}{c}{ Metode } \\
\hline 1 & Identifikasi Kebutuhan Masyarakat & Wawancara dan Observasi Langsung \\
2 & Perancangan & Diskusi \\
3 & Pembuatan & Sosialisasi, praktek dan diskusi \\
4 & Uji Operasi & Pengamatan \\
5 & Pendampingan Operasional & Diskusi, praktek dan tanya jawab \\
6 & Diseminasi teknologi tersebut kepada & Diskusi, praktek dan tanya jawab \\
& masyarakat/mitra & \\
\hline
\end{tabular}

\section{HASIL}

Identifikasi kebutuhan masyarakat dilakukan oleh Tim Pelaksana Kegiatan dengan melakukan observasi dan wawancara langsung dengan Ketua Gapoktan Margo Mukti dan Bumdes Desa Karangpaing, Kecamatan Penawangan, Kabupaten Grobogan. Berdasarkan hasil identifikasi diketahui bahwa Desa Karangpaing termasuk penghasil kacang hijau di Grobogan. Namun, pengolahan pasca panen masih manual sehingga produksinya masih kecil. Mayoritas kacang hijau dijual masih dalam bentuk tanpa pengolahan.

Pada tahap perancangan telah dilakukan perencanaan pengadaan alat teknologi tepat guna. Perancangan dan pembuatan alat dilakukan di Universitas PGRI Semarang. Selain itu, juga dirancang pelatihan penggunaan alat, pengolahan kacang hijau untuk meningkatkan nilai 
tambah dan model pemasarannya.

Pada tahap pembuatan, spesifikasi alat disesuaikan dengan karakteristik dan kebutuhan pengguna yaitu mudah dipindahkan sehingga bias langsung dibawa ke ladang ataupun di rumah.

Pada tahap uji operasi perwakilan dari masing-masing gapoktan dipersilakan mencoba alat dan memberikan umpan balik. Pada tahap ini perwakilan gapoktan sudah puas dengan alat yang telah dibuat. Spesifikasi alat pengupas kulit ari kacang hijau yang di diseminasikan yaitu: kapasitas $3 \mathrm{Kg} /$ menit dengan kapasitas produksi rata-rata perhari $1440 \mathrm{~kg}$, dimensi $30 \mathrm{~cm}$ x $30 \mathrm{~cm}$ x $25 \mathrm{~cm}$, diameter Roller 10 mm, jumlah Sirip 16 buah, bahan Material baja, penggerak manual menggunakan model sepeda kayuh, dan fungsi untuk mengupas kulit ari kacang hijau.

Pendampingan operasional telah dilakukan melalui pelatihan yang diikuti oleh seluruh anggota gapoktan dan karangtaruna Desa Karangpaing.

Hasil diseminasi ini yaitu: Mitra (Gapoktan Margo Mukti dan Bumdes desa Karangpaing) mengetahui, memahami dan mampu menerapkan teknologi pengolahan kacang hijau. Mesin pengupas kulit ari kacang hijau berupa mesin dengan model sepeda kayuh dalam pengelolaan olahan kacang hijau. Penerapan Mesin pengupas kulit ari kacang hijau model sepeda kayuh mampu meningkatkan nilai ekonomi olahan kacang hijau yang dikelola mitra. Harga jual rata-rata $1 \mathrm{~kg}$ kacang hijau kering dalam bentuk asal sebesar $\mathrm{Rp}$ $18.500 / \mathrm{kg}$, sementara jika dijual dengan penerapan teknologi tepat guna rata-rata dengan variasi olahannya seperti bakpao, bakpia dan susu sari kacang hijau menjadi Rp 25.000/kg. Biaya pengolahan kacang hijau asal menjadi olahan kacang hijau diperkirakan sebesar Rp 18.500/kg sehingga terjadi peningkatan nilai tambah (added value) sebesar Rp 6.500/kg. Dalam pengeloaan kacang hijau ini terjadi efisiensi yang cukup nyata dengan harga jual $18.500 / \mathrm{kg}$ bahan mentah menjadi $\mathrm{Rp} 25.000 / \mathrm{kg}$ dengan dimodifikasi olahannya seperti susu sari kacang hijau, bakpao dan bakpia kacang hijau. Keberadaan alat ini, produksi olahan kacang hijau yang semula $50 \mathrm{~kg} /$ hari dapat ditingkatkan menjadi $1440 \mathrm{~kg} / \mathrm{hari}$.

Pada penerapan teknologi ini telah diserahterimakan 5 (lima) unit mesin pengupas kulit ari kacang hijau. Peralatan tersebut dikelola oleh gapoktan Margo Mukti dan Bumdes Desa Karangpaing.

\section{PEMBAHASAN}

Diseminasi teknologi tepat guna tentang mesin pengupas kulit ari kacang hijau telah diberikan sebanyak 5 unit alat pengupas kulit ari kacang hijau kepada 
gapoktan Desa Karang Paing Kecamatan

Penawangan Kabupaten Grobogan. Uji coba mesin pengupas kulit ari kacang hijau ditunjukkan pada Gambar 1.

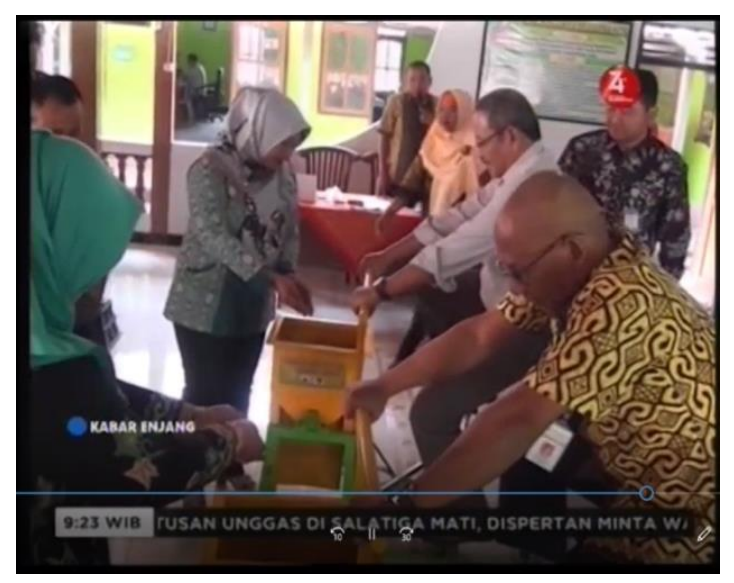

Gambar 1. Uji coba alat pengupas kulit ari kacang hijau

Uji coba ini dilakukan untuk menumbuhkan rasa percaya warga terhadap kebermanfaatan alat yang di desiminasikan.

Hal ini senada dengan diseminasi teknologi mesin genset tenaga surya bagi masyarakat terdampak bencana Gunung Merapi desa Wukirsari, Kecamatan Cangkringan bahwa uji coba sangat penting untuk meningkatkan animo dan pengetahuan warga dalam pengoperasian alat dan teknologi baru (Buchori dkk., 2019).

Ujicoba dan demonstrasi alat/mesin baru juga penting dalam mengurangi kemungkinan kerusakan mesin karena malpraktik sehingga keberadaan mesin/teknologi baru dapat dirasakan kebermanfaatannya lebih besar bagi warga (Novita dkk., 2019).
Hasil ujicoba alat yang dilakukan, mitra telah menguasai dalam mengoperasikan mesin pengupas dengan pendampingan dan tanpa pendampingan. Semua alat pengupas kulit ari kacang hijau ini disimpan di gudang Gapoktan di Balaidesa Karangpaing agar digunakan secara jelas dan aman.

Kemudian setelah dilakukan ujicoba produk, pelatihan selanjutnya adalah pembuatan olahan kacang hijau yang variatif selama 1 hari penuh. Variasi olahan ini antara lain, bakpao lebah, roti bumbu, dan sari kacang hijau. Kegiatan pelatihan ditunjukkan pada Gambar 2.

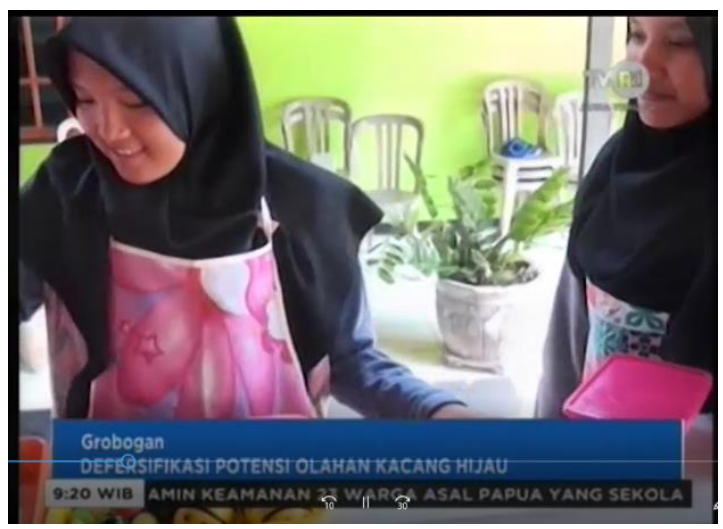

Gambar 2. Tim pelatih terkait pelatihan olahan kacang hijau dari Semarang

Pelatihan pengolahan kacang hijau juga diikuti oleh Ibu-Ibu PKK Desa Karangpaing. Tim Pengabdi melengkapi dengan pemberian informasi mengenai manfaat sari kacang hijau. Manfaat sari kacang hijau yang disampaikan antara lain, sari kacang hijau dapat meningkatkan kadar hemoglobin ibu hamil (Retnorini 
dkk., 2017)

Selain itu, dijelaskan bahwa berdasarkan penelitian, sari kacang hijau dapat meningkatkan produksi ASI bagi ibu yang sedang menyusui (Wulandari \& Jannah, 2015).

Sari kacang hijau juga lebih efektif untuk fermentasi bakteri baik atau probiotik dibanding kacang merah sehingga bermanfaat bagi kesehatan jika dikonsumsi sebagai makanan (Kurniasih \& Rosahdi, 2013).

Antusiasme warga dan Ibu PKK dalam mengikuti pelatihan variasi olahan ini sangat tinggi. Hal ini disebabkan karena variasi hasil olahan akan dapat menjadi tambahan pemasukan bagi warga Desa Karangpaing. Hal ini selaras dengan penelitian dan pengabdian sebelumnya bahwa dengan memberikan keterampilan kepada warga, warga dapat berdaya dalam membuka peluang berwirausaha (Widiastuti dkk., 2018).

Diseminasi mesin pengupas kacang hijau ini melibatkan tiga unsur yaitu warga, perangkat desa, dan Ristekdikti untuk mengoptimalkan efisiensi dan efektivitas pemberdayaan masyarakat (Kusumaningsih dkk., 2019).

\section{SIMPULAN}

Masyarakat Desa Karangpaing Kecamatan Penawangan Kabupaten
Grobogan telah dapat menggunakan alat pengupas kulit ari kacang hijau yang telah didesiminasikan. Lebih dari itu, mereka telah dapat mempraktikkan pembuatan aneka makanan olahan kacang hijau seperti bakpao lebah, roti bumbu, dan sari kacang hijau.

\section{SARAN}

Saran dari penerapan teknologi ini yaitu partisipasi masyarakat baru sebatas gapoktan perlu diperluas dengan melibakan karang taruna khususnya dalam pemasaran online. Lebih dari itu, kerjasama pemerintah dan pihak swasta di sekitar Grobokan perlu dioptimalkan untuk memperluas akses pasar.

\section{UCAPAN TERIMA KASIH}

Ucapan terima kasih kami sampaikan pada kementrian Ristekdikti yang telah memberikan hibah diseminasi ini. Ucapan terima kasih juga kami sampaikan pada perangkat Desa Karang Paing yang telah memfasilitasi tempat dan mengkoordinir warga.

\section{DAFTAR PUSTAKA}

Buchori, A., Widodo, S., Ristanto, S., \& Artiani, L. E. (2019). Diseminasi Teknologi Mesin Genset Tenaga Surya Bagi Masyarakat Terdampak Bencana Gunung Merapi Desa 
Wukirsari Kecamatan Cangkringan

Kabupaten Sleman. Journal of

Dedicators Community, 3(2), 8290.

Kurniasih, N., \& Rosahdi, T. D. (2013). Perbandingan Efektivitas Sari Kacang Merah dan Kacang Hijau sebagai Media Pertumbuhan Lactobacillus acidophilus. Prosiding Seminar Nasional Sains Dan Teknologi Nuklir.

Kusumaningsih, W., Saptaningrum, E., Ulfah, M., \& Khalimah, K. (2019). Pemberdayaan Masyarakat Melalui Pengembangan Desa Sentra Kopi Rempah. Abdimas Altruis: Jurnal Pengabdian Kepada Masyarakat, 1(2), 66-70.

Novita, M., Buchori, A., \& Mujahidin, A. (2019). Diseminasi Teknologi Mesin Perajang Tembakau dalam Upaya Menerapkan Ekoteknologi di Desa Tumbrasanom Kecamatan Kedungadem Kabupaten Bojonegoro. Journal of Dedicators Community, 3(2), 91-98.

Retnorini, D. L., Widatiningsih, S., \& Masini, M. (2017). Pengaruh pemberian tablet Fe dan sari kacang hijau terhadap kadar hemoglobin pada ibu hamil. Jurnal kebidanan, 6(12), 8-16.
Widiastuti, T., Anandha, A., \& Widyaswati,

$\mathrm{R}$.

(2018).

Peningkatan

Kesejahteraan

Keluarga Melalui Pelatihan

Wirausaha Produk Camilan Sehat

Stik Seafood bagi Ibu Rumah

Tangga di Kelurahan Mlatibaru

Semarang. Journal of Dedicators Community, 2(1), 17-26.

Wulandari, D. T., \& Jannah, S. R. (2015).

Pengaruh Pemberian Sari Kacang Hijau pada Ibu Nifas dengan Kelancaran Produksi ASI di BPM Yuni Widaryanti, Amd. Keb Sumbermulyo Jogoroto Jombang. Eduhealth, 5(2).

Zuhri, M. S., Nuvitalia, D., \& Herlambang, B. A. (2019). Program pengembangan kewirausahaan di Unversitas PGRI Semarang. Prosiding Seminar Nasional Unimus, 2. 